4. De Craeye S, Speybroeck N, Ajzenberg D, Dardé ML, Collinet F, Tavernier $\mathrm{P}$, et al. Toxoplasma gondii and Neospora caninum in wildlife: common parasites in Belgian foxes and Cervidae? Vet Parasitol. 2011;178:64-9. https://doi.org/10.1016/j.vetpar.2010.12.016

5. Cruickshank JJ, Haines DM, Palmer NC, St Aubin DJ. Cysts of a Toxoplasma-like organism in an Atlantic bottlenose dolphin. Can Vet J. 1990;31:213-5.6. Van Bressem MF, Duignan PJ, Banyard A, Barbieri M, Colegrove KM, De Guise $S$, et al. Cetacean morbillivirus: current knowledge and future directions. Viruses. 2014;6:5145-81. https:// doi.org/10.3390/v6125145

7. Duignan PJ, Van Bressem MF, Baker JD, Barbieri M, Colegrove KM, De Guise S, et al. Phocine distemper virus: current knowledge and future directions. Viruses. 2014;6:5093-134. https:// doi.org/10.3390/v6125093

8. Hernández M, Robinson I, Aguilar A, González LM, López-Jurado LF, Reyero MI, et al. Did algal toxins cause monk seal mortality? Nature. 1998;393:28-9. https://doi.org/10.1038/29906

9. Barbieri MM, Kashinsky L, Rotstein DS, Colegrove KM, Haman KH, Magargal SL, et al. Protozoal-related mortalities in endangered Hawaiian monk seals Neomonachus schauinslandi. Dis Aquat Organ. 2016;121:85-95. https:/ / doi.org/10.3354/dao03047

10. Robinson SJ, Barbieri MM, Murphy S, Baker JD, Harting AL, Craft ME et al. Model recommendations meet management reality: implementation and evaluation of a network-informed vaccination effort for endangered Hawaiian monk seals. Proc Biol Sci. 2018; 285:20171899. https:/ / doi.org/10.1098/rspb.2017.1899

Address for correspondence: Sandro Mazzariol, Department of Comparative Biomedicine and Food Science, Viale dell'Università 16, 35020, Legnaro (PD), Italy; email: sandro.mazzariol@unipd.it

\section{Increased Likelihood of Detecting Ebola Virus RNA in Semen by Using Sample Pelleting}

\author{
Courtney M. Bozman, Mosoka Fallah, \\ Michael C. Sneller, Catherine Freeman, \\ Lawrence S. Fakoli III, Bode I. Shobayo, \\ Bonnie Dighero-Kemp, Cavan S. Reilly, Jens H. Kuhn, \\ Fatorma Bolay, Elizabeth Higgs, Lisa E. Hensley \\ Author affiliations: National Institutes of Health, Frederick, \\ Maryland, USA (C.M. Bozman, B. Dighero-Kemp, J.H. Kuhn, \\ L.E. Hensley); National Public Health Institute of Liberia,
}

Monrovia, Liberia (M. Fallah, C. Freeman, L.S. Fakoli III, B.I. Shobayo, F. Bolay); National Institutes of Health, Bethesda, Maryland, USA (M.C. Sneller, E. Higgs); University of Minnesota, Minneapolis, Minnesota, USA (C.S. Reilly)

DOI: https://doi.org/10.3201/eid2704.204175

Ebola virus RNA can reside for months or years in semen of survivors of Ebola virus disease and is probably associated with increased risk for cryptic sexual transmission of the virus. A modified protocol resulted in increased detection of Ebola virus RNA in semen and improved disease surveillance.

Doir uring 2013-2016, Ebola virus (EBOV; family Filoviridae, genus Ebolavirus, species Zaire ebolavirus) caused an unprecedented outbreak of Ebola virus disease (EVD) that began in Guinea and subsequently affected Liberia, Sierra Leone, and, to a much lesser degree, several other countries in West Africa. Due in part to the lack of medical infrastructure and response preparedness in these countries, the outbreak ultimately involved 28,652 human infections and 11,325 deaths $(1,2)$.

The large number of EVD survivors enabled detailed studies, such as the Partnership for Research on Ebola Virus (PREVAIL) III study (3), which aimed at characterizing potential EVD sequelae and EBOV persistence in a cohort of 1,144 EVD survivors in Liberia over the course of 5 years. An unexpected observation of these studies was the persistence of EBOV RNA and sometimes-replicating EBOV in the brain, eyes, and semen of survivors (4). EBOV RNA persistence in semen of EVD survivors, measurable up to 40 months $(3,5)$, has been associated with rare events of sexual EBOV transmission and EVD outbreak flareups (6).

Assuming a causal relationship between EBOV RNA and EBOV presence in semen, we collaborated with the overseas response team to initiate an ongoing (and unpublished) trial, PREVAIL IV, to counter sexual EBOV transmission from survivors through reduction of viral RNA concentrations in semen by using the candidate medical countermeasure remdesivir. However, interpretation of data obtained in studies such as PREVAIL IV is crucially dependent on the sensitivity of EBOV RNA detection in semen samples.

The GeneXpert Systems (Cepheid, https://www. cepheid.com) are diagnostic platforms that implement single-use cartridges to simultaneously extract and detect RNA by using reverse transcription PCR. During PREVAIL III (3), the GeneXpert IV System was applied to standard processing of EBOV survivor semen 
Table. Number of positive samples detected in whole semen samples versus pelleted semen samples for detection of Ebola virus RNA* $^{*}$

\begin{tabular}{lccc}
\hline Method: replicate & No. samples & No. invalid samples & No. (\%) Ebola virus RNA positive samples \\
\hline Whole sample: A & 1,661 & 66 & $50(3.1)$ \\
Whole sample: B & 1,661 & 112 & $45(2.9)$ \\
Pellet sample: A & 1,661 & 85 & $84(5.3)$ \\
Pellet sample: B & 1,661 & 69 & $73(4.6)$ \\
\hline${ }^{*}$ Also included are no. invalid samples (i.e., those that did not pass 1 or both of the controls (sample processing control and probe check control). \\
\hline
\end{tabular}

samples using EBOV nucleoprotein and glycoprotein RNA-specific GeneXpert cartridges Cepheid) (7): 100 $\mu \mathrm{L}$ of semen sample was transferred directly into 2.5 $\mathrm{mL}$ of lysis buffer provided in the kit and incubated for $10 \mathrm{~min}$, followed by a second incubation of $5 \mathrm{~min}$ in presence of $100 \mu \mathrm{L}$ of $1 \mathrm{M}$ dithiothreitol (SigmaAldrich, https://www.sigmaaldrich.com). Within $30 \mathrm{~min}$ of processing, $1 \mathrm{~mL}$ of this solution was then loaded into the cartridge, run according to the manufacturer's instructions, and analyzed with GeneXpert Diagnostic Software (8).

We sought to further increase the EBOV RNA detection sensitivity (then $3.1 \%$ and $2.9 \%$ with whole samples) of this protocol for semen. For this experiment, 1,661 EVD survivor samples and nonsurvivor controls from PREVAIL III and IV with sample volumes $\geq 1.6 \mathrm{~mL}$ were divided into 2 cohorts and processed either as described above (whole sample) or first pelleted (pellet sample) by using 2 replicate experiments each (A and B).

For pelleting, we centrifuged $300 \mu \mathrm{L}$ of each semen sample at $10,000 \times g$ for $10 \mathrm{~min}$. After pelleting, we discarded supernatants, resuspended pellets by pipetting in $100 \mu \mathrm{L}$ of kit-provided lysis buffer and incubated for $10 \mathrm{~min}$, and incubated for $5 \mathrm{~min}$ in presence of $100 \mu \mathrm{L}$ of $1 \mathrm{M}$ dithiothreitol. Then, we loaded $100 \mu \mathrm{L}$ of each sample onto cartridges and processed the same way as the standard, unpelleted control sample. Samples were considered valid and positive when both the kitprovided sample processing control and probe check control passed kit criteria and EBOV nucleoprotein or glycoprotein RNA was detected.

Overall, an average of $3.0 \%$ of the whole sample-cohort was positive, compared with an average of $5.0 \%$ of the pellet-sample cohort, thereby almost doubling the detection rate $(\mathrm{p}<0.0001)$ (Table). We observed variability among replicates A and B $(0.7 \%$ for the pellet and $0.2 \%$ for the whole sample), but this difference was not significant $(p=0.35)$ according to the F-test for the equality of 2 variances.

Mixed-effects logistic regression models appropriate to the study design (with random effects for specimens and random effects for replicates nested within specimens) yielded an estimated relative sensitivity of 2.24 (95\% CI 1.51-2.98; p<0.0001) in favor of the pellet-based procedure. Thus, when semen sample volumes from EVD survivors are $>300 \mu \mathrm{L}$, we recommend pelleting $300 \mu \mathrm{L}$ to increase the EBOV RNA detection rate and using the GeneXpert IV System.

\section{Acknowledgment}

We thank Anya Crane for critically editing the manuscript.

This study was supported in part by the Laulima Government Solutions prime contract with the US National Institute of Allergy and Infectious Diseases (contract no. HHSN272201800013C to C.M.B. and B.D.-K.).

J.H.K. performed this work as an employee of Tunnell Government Services, a subcontractor of Laulima Government Solutions (contract no. HHSN272201800013C).

\section{About the Author}

Ms. Bozman is a response support scientist at the National Institute of Allergy and Infectious Diseases, National Institutes of Health, Frederick, MD. Her primary research interest is outbreak response in an international setting.

\section{References}

1. Decroo T, Fitzpatrick G, Amone J. What was the effect of the West African Ebola outbreak on health programme performance, and did programmes recover? Public Health Action. 2017;7(Suppl 1):S1-2. https:/ / doi.org/10.5588/ pha.17.0029

2. Bullard SG. A day-by-day chronicle of the 2013-2016 Ebola outbreak. Springer: Cham (Switzerland); 2018 [cited 2021 Jan 1]. https:/ /link.springer.com/chapter/10.1007/ 978-3-319-76565-5_8

3. Sneller MC, Reilly C, Badio M, Bishop RJ, Eghrari AO, Moses SJ, et al.; PREVAIL III Study Group. A longitudinal study of Ebola sequelae in Liberia. N Engl J Med. 2019;380:924-34. https:/ / doi.org/10.1056/NEJMoa1805435

4. Jacob ST, Crozier I, Fischer WA II, Hewlett A, Kraft CS, Vega MA, et al. Ebola virus disease. Nat Rev Dis Primers. 2020;6:13. https://doi.org/10.1038/s41572-020-0147-3

5. Keita AK, Vidal N, Toure A, Diallo MS, Magassouba N, Baize S, et al.; PostEbogui Study Group. A 40-month follow-up of Ebola virus disease survivors in Guinea (PostEbogui) reveals long-term detection of Ebola viral ribonucleic acid in semen and breast milk. Open Forum Infect Dis. 2019;6:ofz482. https:/ / doi.org/10.1093/ofid/ ofz482

6. Schindell BG, Webb AL, Kindrachuk J. Persistence and sexual transmission of filoviruses. Viruses. 2018;10:683. https://doi.org/10.3390/v10120683 
7. Loftis AJ, Quellie S, Chason K, Sumo E, Toukolon M, Otieno Y, et al. Validation of the Cepheid GeneXpert for detecting Ebola virus in semen. J Infect Dis. 2017;215:344-50.

8. Pettitt J, Higgs E, Fallah M, Nason M, Stavale E, Marchand J, et al. Assessment and optimization of the GeneXpert diagnostic platform for detection of Ebola virus RNA in seminal fluid. J Infect Dis. 2017;215:547-53.

Address for correspondence: Lisa E. Hensley, Integrated Research Facility at Fort Detrick, Division of Clinical Research, National Institute of Allergy and Infectious Diseases, National, Institutes of Health, B-8200 Research Plaza, Fort Detrick, Frederick, MD 21702, USA; email: lisa.hensley@nih.gov

\section{Polyresistant Mycobacterium bovis Infection in Human and Sympatric Sheep, Spain, 2017-2018}

\author{
Bernat Pérez de Val, Beatriz Romero, \\ María Teresa Tórtola, Laura Herrera León, \\ Pilar Pozo, Irene Mercader, Jose Luís Sáez, \\ Mariano Domingo, Enric Vidal
}

\begin{abstract}
Author affiliations: Institut de Recerca i Tecnología
Agroalimentàries-Centre de Recerca en Sanitat Animal, Barcelona, Spain (B. Pérez de Val, M. Domingo, E. Vidal); VISAVET-Universidad Complutense de Madrid, Madrid, Spain (B. Romero, P. Pozo); Vall d'Hebron Research Institute, Barcelona (M.T. Tórtola); Instituto de Salud Carlos III, Majadahonda, Madrid (L.H. León); MAEVA SERVET, S.L., Madrid (P. Pozo); Department d'Agricultura, Ramaderia, Pesca i Alimentació de la Generalitat de Catalunya, Barcelona (I. Mercader); Ministerio de Agricultura, Pesca y Alimentación, Madrid (J.L. Sáez); Universitat Autònoma de Barcelona, Barcelona (M. Domingo)
\end{abstract}

DOI: https://doi.org/10.3201/eid2704.204467

The main etiologic agent of tuberculosis (TB) in livestock is Mycobacterium bovis; human TB cases caused by $M$. bovis are rare. Analysis of a TB outbreak caused by polyresistant $M$. bovis involving a human and sympatric sheep in Spain suggests local circulation of drug-resistant $M$. bovis strains among livestock.
The main etiologic agent of tuberculosis (TB) in 1 livestock and wildlife is Mycobacterium bovis. This species also infects humans through inhalation or ingestion and causes TB that is clinically indistinguishable from that caused by $M$. tuberculosis.

In 2017, a case of pulmonary TB caused by $M$. bovis in a human was detected in the Vall d'Hebron Hospital in Barcelona, Spain. Bacteriological culture of clinical specimens in Löwenstein-Jensen and 7H9 media (BD Diagnostics, https://bd.com), followed by antimicrobial resistance testing (BACTEC MGIT 960; BD Diagnostics), revealed a strain resistant to 2 first-line anti-TB drugs: pyrazinamide $(100 \mu \mathrm{g} /$ $\mathrm{mL})$ and isoniazid $(0.1 \mu \mathrm{g} / \mathrm{mL})$. A complementary analysis, performed by using the proportion method, confirmed resistance to isoniazid $(0.2 \mu \mathrm{g} / \mathrm{mL})$, elucidating a polyresistant case of TB (resistance to $>1$ first-line anti-TB drug other than both isoniazid and rifampin); the strain was also resistant to ethionamide $(30 \mu \mathrm{g} / \mathrm{mL})$, an antimicrobial drug specifically used to treat active multidrug-resistant TB (resistance to at least both isoniazid and rifampicin). Molecular characterization by direct variable repeat (DVR)-spoligotyping identified the isolates as M. bovis spoligopattern SB0124 (http:/ / www.mbovis.org).

The patient worked as a farmer on cattle and small ruminant farms in his county. Therefore, the epidemiologic investigation included the livestock he was in contact with, particularly the herd of sheep and goats he was currently managing. In 2018, a total of $34(25 \%)$ ewes and $3(18 \%)$ goats had positive results to a single intradermal tuberculin test, interferon gamma release assay (IDvet, https://www.idvet.com), or both. Animals with positive test results were slaughtered, and tissues from 23 (21 sheep and 2 goats) were examined postmortem. TB-compatible lesions were found in the lungs and thoracic, mesenteric, or ileocecal lymph nodes of 13 animals (12 sheep, 1 goat). Tissues with lesions were cultured in Löwenstein-Jensen with pyruvate and Coletsos and in 7H9 media by using BACTEC MGIT 320 (all BD Diagnostics). Culture indicated growth of $M$. tuberculosis complex in 9 sheep samples, and M. avium subspecies avium was isolated from another sheep and the goat. DVR-spoligotyping was performed for the $9 \mathrm{M}$. tuberculosis complex isolates, and M. bovis SB0124 was identified in all. This unusual spoligopattern had also been identified in a cattle herd in the same county in 2005 (Spanish Database of Animal Mycobacteriosis; https://www.visavet.es/mycodb); the patient had no known connection to that herd.

Genome sequence analysis based on assessment of single-nucleotide polymorphisms (SNPs) 